\title{
ARYSTOTELES O MOŻLIWOŚCI BYCIA NIESPRAWIEDLIWYM WOBEC SAMEGO SIEBIE
}

\author{
- Maciej Smolak -
}

\begin{abstract}
Abstrakt. Przedmiotem tego artykułu jest rozjaśnienie sensu aporii „czy można być niesprawiedliwym wobec samego siebie?", którą Arystoteles rozważa w EN V, oraz wykazanie, że możliwe jest dobrowolne traktowanie niesprawiedliwie samego siebie. Na uwagę zasługują szczególnie dwa miejsca V 9, czyli ustępy 1136a31-1136b1 oraz 1136b13-25. W pierwszym ustępie Arystoteles wysuwa hipotezę, że akratyk może dobrowolnie traktować niesprawiedliwie samego siebie. W drugim przedstawia dwa argumenty - „z pozornej straty” oraz „z życzenia” - które mają za zadanie udowodnienie, że nikt nie może traktować niesprawiedliwie samego siebie. Argumenty te nie unieważniają hipotezy wysuniętej w pierwszym ustępie ani nie wykluczają możliwości dobrowolnego traktowania niesprawiedliwie samego siebie.
\end{abstract}

Słowa kluczowe: akrazja, Arystoteles, niedobrowolny, niesprawiedliwe traktowanie, traktować niesprawiedliwie, osoba nieopanowana, dobrowolny.

Published online: 1 November 2020

\section{Wprowadzenie}

Arystoteles poszukuje w Etyce nikomachejskiej [EN] odpowiedzi na pytanie, „jaki typ życia jest dla człowieka najbardziej odpowiedni i najlepszy?". W tym celu przeprowadza badanie służące ustaleniu, czym jest najwyższe dobro możliwe do osiągnięcia przez człowieka. Co do nazwy tego dobra, panuje powszechna zgoda, ponieważ zarówno ludzie prości, jak i wykształceni, określają je eudaimonia (I 4, 1095a17). Ale odpowiedź na pytania, „czym jest eudaimonia?” (1095a20) oraz „jaki sposób życia jest najbardziej eudaimoniczny?" (I 5, 1095b15) są już bardziej zróżnicowane. Jedni upatrują eudaimonię w prowadzeniu życia hedonistycznego, inni zrównują ją z życiem zogniskowanym na aktywności politycznej, jeszcze inni identyfikują ją z życiem skoncentrowanym na aktywności teoretycznej (1095b16-19)1.

W ustępie EN I 7 Arystoteles formułuje argument z funkcji, na podstawie którego dochodzi do wniosku, że eudaimonia jest aktywnością psuchē, realizowaną zgodnie

Maciej Smolak

Instytut Filozofii UJ

ul. Grodzka 52

31-044 Kraków

email: maciej.smolak@uj.edu.pl

${ }^{1}$ W Etyce eudemejskiej [EE] I 4, 1215b34-1215b1 Arystoteles zaznacza, że istnieją trzy największe ludzkie dobra - doskonałość, mądrość, przyjemność - i dlatego każdy człowiek, jeśli ma tylko sposobność wyboru, decyduje się na życie polityczne, filozoficzne lub hedonistyczne. 
z przynależącymi do niej doskonałościami (1098a16). Mówiąc o doskonałościach Sta-

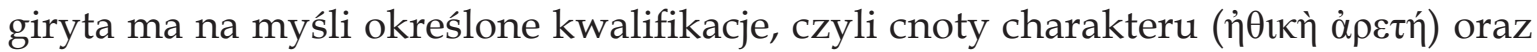

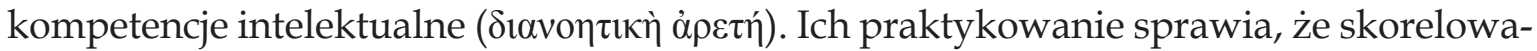
ne z nimi aktywności psuchē są realizowane perfekcyjnie i należą do konstytutywnych składników eudaimonii (por. np. VII 13, 1153b16-17).

Panuje wprawdzie powszechna zgoda, gdy chodzi o nazwy owych doskonałości w szczególności cnót charakteru (np. męstwo, hojność, czy sprawiedliwość) - ale nie ma już takiej zgody, co do odpowiedzi na pytanie, czym one są i jaka jest ich rola z punktu widzenia prowadzenia eudaimonicznego życia. Aby więc uszczegółowić zarysowane jedynie w konturach rozumienie eudaimonii, Arystoteles przeprowadza badanie, którego celem jest dookreślenie doskonałości wymaganych dla jej osiągnięcia. W kolejnych księgach EN formułuje więc definicję cnoty charakteru (II), charakteryzuje podstawowe fenomeny odgrywające kluczową rolę w wyjaśnieniu, pod jakimi warunkami człowiek jest sprawcą działania i może być za nie pociągnięty do odpowiedzialności ${ }^{2}$ (III), wyjaśnia, czym są i jakie są konkretne cnoty charakteru (IV), ze szczególnym uwzględnieniem sprawiedliwości (V), oraz opisuje poszczególne kompetencje intelektualne, zwłaszcza mądrość praktyczną ( $\varphi \rho o ́ v \eta \sigma ı)$ i jej relację do cnoty charakteru (VI).

Księga VI zamyka refleksję na temat cnót charakteru i kompetencji intelektualnych, ale nie jest zwieńczeniem prowadzonych analiz, ponieważ nie kończy się próbą rozwiązania problemu postawionego w punkcie wyjścia. Arystoteles nie formułuje w księdze VI ostatecznej odpowiedzi na pytanie ,jaki typ życia jest dla człowieka najbardziej odpowiedni i najlepszy?" - czyni to dopiero w X 7-8 - lecz przechodzi do rozpatrzenia trzech kwestii, jego zdaniem ściśle powiązanych z zagadnieniem eudaimonii, czyli kwestii akrazji ${ }^{4}$ (VII 1-10) ${ }^{5}$, przyjemności (VII 11-14 i X 1-5) ${ }^{6}$ oraz przyjaźni (VIII i IX) ${ }^{7}$.

\footnotetext{
${ }^{2}$ Na temat zagadnienia odpowiedzialności u Arystotelesa zobacz np.: Arnold (2001), Bondeson (1974), Bostock (2000), Irwin (1980), Kenny (1998), Meyer (1993, 2006). Ale por. np. Hursthouse (1984), która podkreśla, że wprawdzie panuje powszechna tendencja, aby EN III 1 rozpatrywać wyłącznie pod kątem zagadnienia moralnej i prawnej odpowiedzialności, sama jednak uważa, że ta część badania jest kontynuacją rozważań Arystotelesa na temat cnoty charakteru.

${ }^{3}$ Arystoteles dochodzi ostatecznie do wniosku, że zarówno życie polityczne jak i życie teoretyczne mają charakter eudaimoniczny. Zastrzega jednak, że aktywność polityczna jest drugorzędną formą eudaimonii w stosunku do aktywności teoretycznej (EN X 8, 1178a9-10). Wyższość drugiej polega na tym, że w największym stopniu spełnia wymogi samowystarczalności - jedno z kryteriów nałożonych na najwyższe dobro możliwe do osiągnięcia przez człowieka (I 7, 1097b20) - ponieważ inaczej niż aktywność polityczna, nie ma ona żadnego innego celu poza samą sobą. Ponadto aktywność teoretyczna pozwala na partycypację w boskości, ponieważ jej praktykowanie zakłada aktywizację rozumu (voṽs), czyli elementu boskiego w nas (X 7, 1177b27-31).

${ }^{4}$ Termin akrazja jest różnie tłumaczony: nieopanowanie, brak opanowania (np. Gromska, [w:] Arystoteles (1956)), niepowściągliwość (incontinence; np. Crisp, [w:] Aristotle (2004)), brak kontroli (lack of control; np. Rowe, [w:] Aristotle (2002)), słabość moralna (moral weakness; np. Hardie (1968)), słabość woli (weakness of the will; np. Natali (2009)). W dalszej części artykułu uciekam się

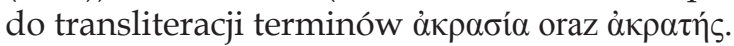

${ }^{5}$ Na temat zagadnienia akrazji u Arystotelesa zobacz np.: Bostock (2000), Charles (2011), Natali (2009), Pakaluk (2005), Price (2011).

${ }^{6}$ Na temat zagadnienia przyjemności u Arystotelesa zobacz np.: Bostock (1988, 2000), Dow (2011), Festugière (1946), Frede (2006), Heinaman (2011), Natali (2009), Ortiz de Landázuri (2012).

${ }^{7}$ Na temat zagadnienia przyjaźni u Arystotelesa zobacz np.: Price (1989), Pakaluk (1998, 2005), Pangle (2004), Smolak (2013), Sowa (2009), Stern-Gillet (1995).
} 
Badanie przyjemności jest istotne dla zrozumienia najwyższego dobra możliwego do osiągnięcia przez człowieka, ponieważ przyjemność jest nieodłącznym atrybutem eudaimonii. Arystoteles zauważa, że eduaimonia jest najlepszą, najpiękniejszą oraz najprzyjemniejszą rzeczą. W jej bowiem przypadku, inaczej niż to sugeruje myśl zapisana na bramie świątyni Latony, dobro, piękno i przyjemność nie są od siebie oddzielone, lecz występują razem (I 8, 1099a24-26). Poza tym, skoro dla każdego to jest przyjemne, odnośnie do czego mówi sobie, że to miłuje (1099a8-9), więc również życie polityczne oraz życie teoretyczne są czymś przyjemnym dla tych, którzy są ich miłośnikami ${ }^{8}$.

W VII 12 Arystoteles sugeruje, że przyjemność jest niezakłóconą aktywnością dyspozycji zgodnej z naturą (1153a14-15), natomiast w X 4 przyjmuje, że przyjemność dopełnia aktywność (1174b23). Oba rozważania, pomimo odmiennego rozumienia przyjemności, dają się jednak uzgodnić ${ }^{9}$, ponieważ eudaimonia z jednej strony jest czymś ostatecznym i samowystarczalnym (I 7, 1097b20), z drugiej zaś jest czymś utworzonym z kompletnych aktywności (VII 13, 1153b16-17). Stąd eudaimonia, jako pewien typ aktywności, musi być również niezakłócona. Ale powiązanie „braku zakłócen”” i „kompletności" pozostaje w ścisłym związku ze stwierdzeniem, że przyjemność dopełnia aktywność i jest rodzajem spełnienia, które dołącza się do niej (X 4, 1174b31-33). Jak zaznacza Arystoteles, z każdą aktywnością skorelowana jest jej właściwa przyjemność, która ją ulepsza ${ }^{10}$. Tak zatem przyjemność potęguje aktywność sprawiając, że jest ona wykonywana lepiej i dokładniej, a więc również bez zakłóceń. O takiej zaś aktywności można powiedzieć, że staje się kompletna, czyli taka, że niczego jej nie brakuje. Z tego jednak, że przyjemność jest nierozłączna z eudaimonią nie wynika, że Arystoteles stoi na stanowisku typowo hedonistycznym i utożsamia przyjemność z najwyższym dobrem. Jest raczej tak, że przyjemność jest rodzajem perfekcji, która towarzyszy każdej aktywności zgodnej z naturą, również najlepszej z nich, czyli aktywności teoretycznej.

Rozważania na temat przyjaźni są ważne z punktu widzenia sformułowania wiążącej odpowiedzi na pytanie, ,,jaki typ życia jest dla człowieka najbardziej odpowiedni i najlepszy?", ponieważ według Arystotelesa człowiek jest istotą obywatelską i z natury skłonną do życia z innymi (IX 9, 1169b18-19). Stąd też przyjaźń może jawić się jako rodzaj wspólnoty, która stwarza optymalne warunki dla zaspokajania naturalnej potrzeby współbytowania i prowadzenia eudaimonicznego życia wespół z drugim człowiekiem. Nie chodzi jednak o dowolną przyjaźń, lecz o przyjaźń opartą na charakterze lub inaczej rzecz ujmując, o przyjaźń powodowaną doskonałością charakteru każdej ze stron relacji. W takiej bowiem przyjaźni przyjaciele przejawiają wzajemną troskę o siebie, co znajduje wyraz w okazywaniu wzajemnej pomocy w czasie niepowodzeń i wzajemnym wspieraniu się w realizowaniu powziętych zamierzeń. Ponadto uczestnictwo tego

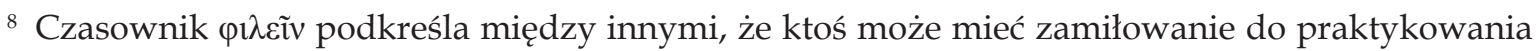

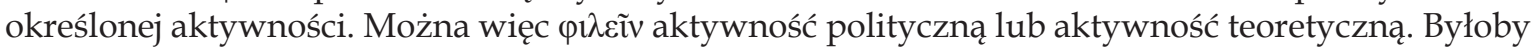
co najmniej dziwne, gdyby ktoś wykonywał daną czynność z zamiłowaniem i równocześnie bez przyjemności.

${ }^{9}$ Komentatorzy starają się w różny sposób wykazać, że nie ma niezgodności między jednym i drugim rozumieniem przyjemności. Por. np. Bostock (1988, 2000), Ortiz de Landázuri (2012), Owen (1971/2). ${ }_{10}$ Por. EN X 5, 1175b13-21. Należy dodać, że każda aktywność ma nie tylko sobie właściwą przyjemność, lecz również sobie właściwą przykrość, choć z przyjemności i przykrości, przynależących do danej aktywności, wynika coś przeciwnego. Pierwsza ją doskonali, druga ją niszczy.
} 
typu przyjaciół we wspólnych rozmowach i wymianie myśli przyczynia się do wzrostu ich twórczej energii oraz sprawia, że ich działalność staje się bardziej ciągła i pełniejsza, co ma istotne znaczenie z punktu widzenia wykładni eudaimonii jako aktywności ${ }^{11}$. Ale umiejscowienie rozważań o przyjaźni między badaniem doskonałości charakteru i doskonałości rozumu, a charakterystyką życia teoretycznego, może też suponować, że Arystoteles traktuje przyjaźń jako rodzaj pomostu między życiem praktycznym i najwyższą formą życia eudaimonicznego ${ }^{12}$.

O ile celem analiz dotyczących przyjemności i przyjaźni jest dopełnienie charakterystyki najwyższego dobra możliwego do osiągnięcia przez człowieka, o tyle badanie akrazji ma inne zadanie. Akrazja jest bowiem typem defektu lub stanu charakteru, który sprawia, że podmiot przestaje być wierny samemu sobie, ponieważ jest nielojalny wobec własnych przekonań lub nie trzyma się posiadanej wiedzy na temat dobra, gdy staje w obliczu możliwości doświadczenia pewnych przyjemności, w szczególności przyjemności cielesnych lub gdy faktycznie ich doświadcza. Tak więc podmiot, mimo że wie lub jest przekonany, co ma zrobić w danej sytuacji, robi jednak coś zupełnie innego. Badanie akrazji ma wyjaśnić, jak jest możliwe, że ktoś, kto posiada wiedzę na temat tego, co dobre, mimo to świadomie postępuje niezgodnie z posiadaną wiedzą. Ma też uwydatnić wartość oraz znaczenie doskonałości charakteru i doskonałości rozumu w funkcji praktycznej dla prowadzenia eudaimonicznego życia.

Problem ten nurtował już Platona. W Protagorasie, który należy do grupy jego wczesnych dialogów, przytacza opinię tych, którzy przyjmują, że ludzie wiedzą, co jest najlepsze w danej sytuacji, a mimo to nie chcą tego uczynić, chociaż leży to w ich mocy, tylko robią coś zupełnie innego (352db6-7). Sam jednak nie podziela takiej opinii i odrzuca możliwość występowania akrazji. Na tym bowiem etapie swojej refleksji akceptuje monistyczną koncepcję psuchē, głoszoną przez Sokratesa, w myśl której psuchē jest istotą człowieka i sprowadza się do rozumu, który jeśli jest wyposażony w wiedzę o tym, co dobre, skutecznie zabezpiecza podmiot przed zło-czynieniem i nie daje się zwieść lub opanować przez irracjonalne pobudki. Ale w czwartej księdze Państwa Platon stoi już na stanowisku pluralistycznej koncepcji psuchē. Przyjmuje, że psuchē składa się z trzech "części" - racjonalnej, zapalczywej i pożądliwej - i że każda z nich posiada jej właściwe naturalne tendencje do działania. Przystaje też na możliwość braku harmonii między irracjonalnymi impulsami pożądliwej lub zapalczywej „części” psuchē, a tym, czego domaga się jej racjonalna „część”. Zakłada więc możliwość pojawienia się wewnętrznego konfliktu między pobudkami psuchē. W rezultacie dopuszcza, że podmiot może uważać, iż jedna rzecz jest wartościowsza od innej i zatem racjonalnie przedkładać pierwszą nad drugą, a mimo to, pod wpływem pobudek apetytywnych, może w praktyce wartościować je odmiennie i działać wbrew ustaleniom rozumu. Platon otwiera tutaj niejako pole do badań nad realnością akrazji, którą odrzucał jeszcze w Protagorasie. Mimo to, głównym przedmiotem jego zainteresowania nie jest akrazja jako taka, lecz natura wewnętrznego konfliktu, jaki zachodzi między pobudkami postępowania, lokującymi się w poszczególnych „częściach” psuchē. Zaskakiwać może jednak artykułowana przez Platona teza

${ }^{11}$ Por. np. Arystotelesa rozwiązanie aporii „czy eudaimōn będzie potrzebował przyjaciela?” w EN IX 9 oraz w EE VII 12.

12 Por. np. Pangle (2004): 199-200. 
asymetryczna, w myśl której dobre działania są dobrowolne, natomiast złe działania są niedobrowolne ${ }^{13}$, co może sugerować, że podmiot jest zwolniony z odpowiedzialności za zło-czynienie.

Z tezą asymetryczną nie zgadza się Arystoteles, czemu daje między innymi wyraz, gdy stwierdza, że „jest czymś śmiesznym czynić odpowiedzialnym nie siebie, lecz rzeczy zewnętrzne, za łatwość bycia usidlonym przez to, co przyjemne i to, co piękne, oraz czynić odpowiedzialnym siebie za dokonanie pięknych rzeczy, a za dokonanie haniebnych rzeczy, to, co przyjemne" (EN III 1, 1110b13-15) $)^{14}$. W kwestii tezy asymetrycznej Stagiryta dyskutuje z Platonem przede wszystkim w III 5 i tam też przedstawia zasadnicze argumenty na rzecz jej odrzucenia ${ }^{15}$. Można jednak postawić pytanie, czy rozważany przez Arystotelesa problem możliwości bycia niesprawiedliwym wobec samego siebie, nie implikuje asymetrycznego rozwiązania. Wszak „być niesprawiedliwym" jest czymś złym i wydaje się, że nikt dobrowolnie nie traktuje niesprawiedliwie samego siebie. Mimo to asymetryczne rozwiązanie problemu staje się mniej oczywiste, gdy weźmie się pod uwagę to, jak samego siebie traktuje akratyk.

Przedmiotem tego artykułu jest próba rozjaśnienia sensu aporii „czy można być niesprawiedliwym wobec samego siebie?” i wykazanie, że możliwe jest dobrowolne traktowanie niesprawiedliwie samego siebie. Arystoteles formułuje aporię w EN V 9 i tam też zarysowuje jej rozwiązanie. Rozpoczynając V 11 Stagiryta stwierdza, iż ,jest jasne, na podstawie tego, co już zostało powiedziane, czy można traktować niesprawiedliwie samego siebie, czy nie" (1138a4-5). Sugerując, że rozwiązanie problemu nie powinno budzić wątpliwości, jeżeli się uwzględni to, co zostało wcześniej powiedziane, Arystoteles ma przede wszystkim na myśli rozważania przeprowadzone w V 9, których celem jest naświetlenie niektórych wątpliwości dotyczących tego, co to znaczy "traktować niespra-

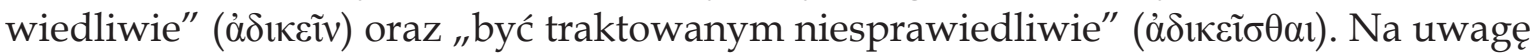
zasługują szczególnie dwa miejsca V 9. Chodzi mianowicie o ustępy 1136a31-1136b1 oraz 1136b13-25.

Należy podkreślić, że Arystoteles bada, co to znaczy „traktować niesprawiedliwie", w tym "traktować niesprawiedliwie samego siebie”, oraz co to znaczy „być traktowanym niesprawiedliwie”, w tym "być traktowanym niesprawiedliwie przez samego

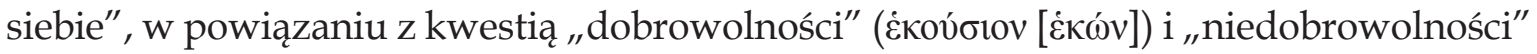

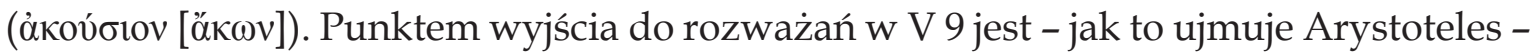
dziwaczna wypowiedź Eurypidesa (1136a12), zaczerpnięta z zaginionej tragedii Alkmeion w Psofidzie. Tytułowy bohater miał bowiem powiedzieć:

"Zabiłem swoją matkę, krótkie to stwierdzenie.

Dobrowolnie, czy nie dobrowolnie [zabiłem], dobrowolnie, czy nie dobrowolnie [dała się zabić]?"16.

\footnotetext{
${ }_{13}$ Na temat tezy o "niedobrowolności zła”, por. np. Prawa V 731c, 734a-b, IX 860d-e. Por. też Zygmuntowicz, [w:] Platon (2017): 258, przyp. 484.

${ }_{14}$ Por. też EN III 1, 1111a27-29. O ile nie zaznaczono inaczej, wszystkie tłumaczenia podaje w przekładzie własnym.

${ }_{15}$ Por. np. Meyer (2006): 151-156.

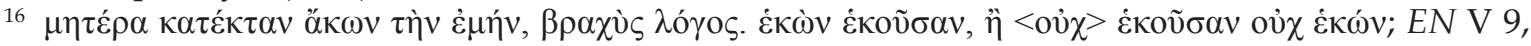
1136a13-14. Warto nadmienić, że Arystoteles nawiązuje do tej samej tragedii w III 1, 1110a28.
} 
Zanim więc odniosę się do ustępów 1136a31-1136b1 oraz 1136b13-25, wyjaśnię w zarysie, czym różni się, zdaniem Arystotelesa, to, co dobrowolne od tego, co niedobrowolne.

\section{To, co dobrowolne i to, co niedobrowolne $\mathrm{e}^{17}$}

Arystoteles dokonuje zazwyczaj reinterpretacji terminów zaczerpniętych z języka potocz-

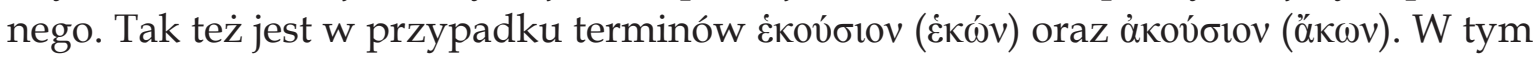
sensie oddawanie ich przez "dobrowolne" i „niedobrowolne”, jak to czyni większość

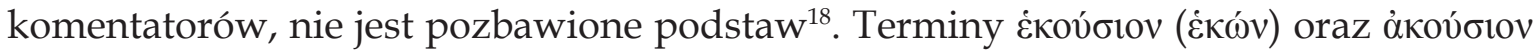
$(\alpha \kappa \omega v)$ miały dwa podstawowe znaczenia - „umyślne-nieumyślne” ${ }^{19}$ oraz „ochotne-

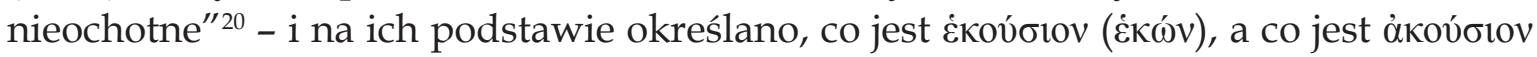

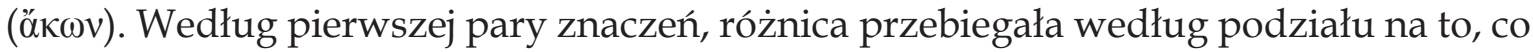
niebezwiedne i bezwiedne, według drugiej - na to, co chciane i niechciane ${ }^{21}$.

Należy jednak podkreślić, że czasami Arystoteles celowo korzysta z wieloznaczności obu terminów i nie stosuje ich w znaczeniu technicznym ${ }^{22}$. Tak jest również - jak się wydaje - w EN V 9, 1136b13-25, a więc w jednym z miejsc, które ma dostarczyć niebudzącego wątpliwości rozwiązania aporii. Może to być o tyle zaskakujące, że rozważania w V 9 następują bezpośrednio po V 8, czyli tej części EN, w której Arystoteles poddaje oba terminy gruntownej analizie oraz wyjaśnia, jak je rozumie.

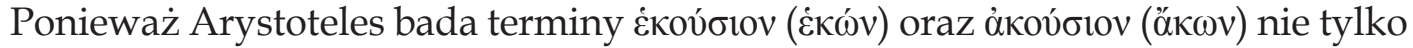
w EN V 8, lecz również w III 1, więc trzeba rozważyć, co Arystoteles mówi na ich temat w obu księgach i do jakich dochodzi ustaleń.

\subsection{To, co dobrowolne i to, co niedobrowolne według EN III 1}

EN III 1 jest miejscem, w którym Arystoteles przeprowadza badanie mające przede wszystkim na celu odróżnienie działań dobrowolnych, od niedobrowolnych ${ }^{23}$. Badanie składa się z dwóch faz. W pierwszej wytyczona zostaje granica pomiędzy działaniem dobrowolnym i niedobrowolnym. Odgraniczenie jest ważne, ponieważ określenie tego,

${ }_{17}$ Na temat dobrowolności i niedobrowolności zobacz np. Galewicz (2003, 2019: 9-156).

18 Por. np.: Bostock (2000); Crisp, [w:] Aristotle (2004); Hardie (1968); Irwin (1980); Ross, [w:] Aristotle (1931); Meyer (2006). Por. jednak np. Moline (1989).

${ }_{19}$ Por. np. Sofokles (2009): w. 964.

${ }^{20}$ Por. np. Ajschylos (1954): w. 671.

${ }^{21}$ Należy podkreślić, że żadne z podstawowych znaczeń nie odróżnia tego, co jest dobrowolne, od tego, jest niedobrowolne. Niektóre działania - na przykład przekazanie szantażyście okupu - są bowiem dobrowolne w myśl pierwszej pary znaczeń, ale niedobrowolne w myśl drugiej.

${ }^{22}$ Por. np. EN III 1, 1110b11-13.

${ }^{23}$ Należy podkreślić, że w otwierającej uwadze EN III 1, Arystoteles zaznacza, że zagadnienie

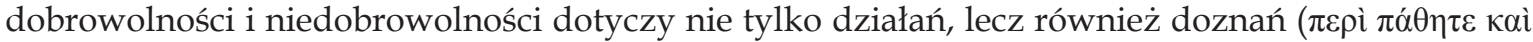

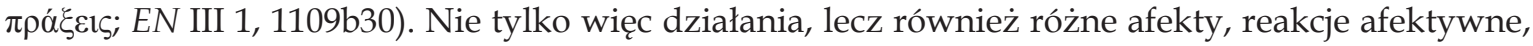
a także bierne zachowania mogą być dobrowolne albo niedobrowolne. Jest to ważne, ponieważ, jak zaznaczyłem we Wprowadzeniu, badanie "traktowania niesprawiedliwie samego siebie” oraz "bycia traktowanym niesprawiedliwie przez samego siebie", wiąże się ściśle z zagadnieniem dobrowolności i niedobrowolności. 
co jest dobrowolne, wskazuje na warunki nałożone na działanie zasługujące na pochwałę lub naganę. Innymi słowy, człowiek może być chwalony lub ganiony za dokonanie danego działania, o ile jest ono dobrowolne. W drugiej fazie zostaje zarysowane dyskretniejsze rozgraniczenie w ramach działań, które są dobrowolne. Arystoteles wyróżnia wśród nich takie, które są realizowane zgodnie z $\pi \rho 0 \alpha i ́ p \varepsilon \sigma ı \varsigma$, a więc wtedy, gdy autor agendi przedsiębierze linię działania, którą uprzednio obmyślił i postanowił zrealizować. Ponieważ V 9, 1136a31-1136b1 nawiązuje do zachowania akratyka, dla którego charakterystyczne jest to, że działa niezgodnie z $\pi \rho \alpha^{\prime} \rho \varepsilon \sigma 1 \varsigma$, drugą fazę badania można tutaj pominąć ${ }^{24}$.

Ogólnie rzecz ujmując, działanie jest niedobrowolne, gdy jest dokonane: A) pod

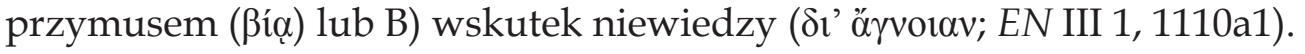

Ad. A) Jak podkreśla Arystoteles, „wymuszone (ßíaıv) jest to, czego zasada

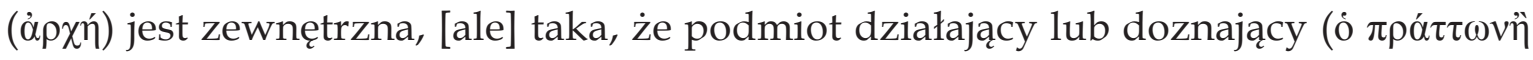
ó $\pi \alpha ́ \sigma \chi \omega v)$ niczym się do niej nie przyczynia" (1110a2-3). W przedstawionej charakterystyce tego, co wymuszone, uwagę przykuwają dwie rzeczy.

Po pierwsze, zasada, która jest przyczyną działania, nie znajduje się w podmiocie, lecz poza nim. Można zasugerować, że chodzi o zasadę, która jest na zewnątrz w stosunku do ciała podmiotu. Jest to o tyle zrozumiałe, że ciało odgranicza cały podmiot od tego, co nim już nie jest ${ }^{25}$. Takie też przykłady zasad zewnętrznych podaje Arystoteles - „na przykład, jeśli wiatr gdzieś go [tzn. podmiot działający lub doznający] uniósł lub ludzie, którzy mają nad nim władzę" (1110a3-4).

Po drugie, podmiot niczym się nie przyczynia do zewnętrznej zasady. Oznacza to, że sprawstwo leży w całości po stronie zasady zewnętrznej. Chodzi więc o taką sytuację, w której podmiot nie odgrywa żadnej roli w przebiegu zdarzenia, ale nie dlatego, że nie podejmuje działania, lecz dlatego, że nic nie może zrobić w sytuacji, w której się znalazł.

Samo jednak ulokowanie zasady działania w podmiocie nie wystarcza do tego, aby działanie było dobrowolne. W EN V 8 Arystoteles wspomina o procesach naturalnych, takich jak starzenie się czy umieranie, których zasada odsyła do psuchē w funkcji żywiennej ${ }^{26}$. Trudno się jednak zgodzić, że proces starzenia się jest dobrowolny lub że podmiot jest jego sprawcą ${ }^{27}$. Dlatego Arystoteles dookreśla warunki, jakie muszą być

\footnotetext{
${ }^{24}$ Jak zauważa Arystoteles, ",

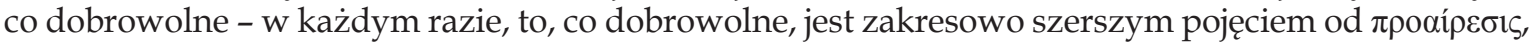
ponieważ nawet dzieci oraz zwierzęta mają udział w tym, co dobrowolne, natomiast nie mają udziału

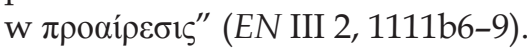

${ }^{25}$ Trzeba podkreślić, że Arystoteles nie jest dualistą, lecz uważa, zgodnie z teorią hylemorfizmu,

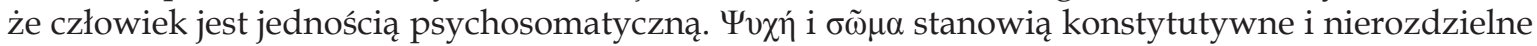
elementy jednej substancji, która jest żywą istotą (por. np. Skowroński (2015): 197-204). Nie zmienia to jednak faktu, że $\sigma \tilde{\mu} \mu \alpha$ wyznacza ostateczną granicę, która oddziela człowieka od zewnętrznego świata.

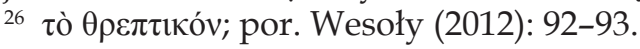

${ }^{27}$ Nasuwa się przypuszczenie, że mówienie o zewnętrznej zasadzie ma sens nie tylko wtedy, gdy jest ona zlokalizowana poza naszym ciałem, lecz również wtedy, gdy jest ona poza nami w sensie na zewnątrz naszej psuchē logicznej, a także alogicznej, lecz w funkcji zmysłowo-orektycznej. Bez względu jednak na to, czy takie przypuszczenie jest zasadne, należy podkreślić, że procesy naturalne np. starzenie się - nie są wymuszone w rozumieniu EN III 1, 1110a2-3 (por. np. Galewicz (2003): 24, przyp. 14). Trzeba więc przyjąć, że procesy tego typu nie są ani dobrowolne, ani niedobrowolne, choć nie ulega wątpliwości, że możemy mieć wpływ na szybkość procesu naszego starzenia się (por. np. Kenny, [w:] Aristotle (2011): 166).
} 
spełnione, aby działanie było dobrowolne. Nie wystarczy, że zasada działania znaj-

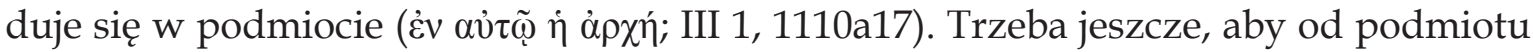

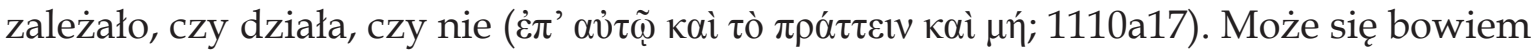
zdarzyć, że zasada działania jest obecna w podmiocie, a mimo to ów drugi warunek nie jest spełniony ${ }^{28}$. Uwzględniając więc kryterium „pod przymusem”, należy przyjąć, że działanie jest dobrowolne, gdy zasada działania znajduje się w podmiocie i od podmiotu zależy, czy działa, czy nie ${ }^{29}$.

Ad B) Według Arystotelesa działanie może wiązać się z dwoma odmiennymi typami niewiedzy - niewiedzą dotyczącą tego, co jest właściwym obiektem dążenia oraz niewiedzą dotyczącą okoliczności działania.

Pierwszy typ niewiedzy Arystoteles określa niewiedzą ogólną (1110b32) i ma przede wszystkim na uwadze nieznajomość tego, do czego warto dążyć i czego należy unikać (1110b28-29). Ktoś, kogo cechuje niewiedza ogólna, nie ma rozeznania jak żyć, aby prowadzić życie najbardziej udane. Nie wie zatem, czym jest najwyższe dobro możliwe do osiągnięcia przez człowieka, ani co jest pożyteczne z punktu widzenia jego realizowalności (1110b31). Zarazem brak takiej wiedzy przyczynia się do tego, że człowiek staje się niesprawiedliwy oraz nikczemny (1110b29-30), a w konsekwencji przestaje się orientować, że jego życie zogniskowane jest na złym celu życiowym. Ale pomimo tej dezorientacji, spowodowanej niewiedzą ogólną, działania takiego człowieka są według Arystotelesa dobrowolne, ponieważ to on ponosi odpowiedzialność za nieznajomość tego, co jest obiektem, do którego warto dążyć ${ }^{30}$. Należy dodać, że Arystoteles, mówiąc o niewiedzy ogólnej, ma też na myśli przesłanki rozumowania praktycznego na temat

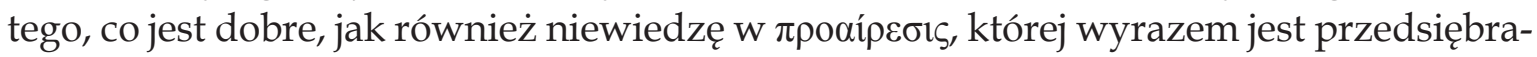
ny cel, będący obiektem czyjegoś dążenia (1110b31).

Drugi typ niewiedzy Arystoteles określa niewiedzą partykularną (1110b33), czyli niewiedzą na temat czynników, mających znaczenie z punktu widzenia realizowanego działania (1110b33-1111a1). Arystoteles wymienia siedem takich czynników - trzeba wiedzieć, kto działa, co robi, wobec kogo, w czym, za pomocą czego, ze względu na

\footnotetext{
${ }^{28}$ Jak zauważa Arystoteles w EE II 8, „nie twierdzimy, że w przypadku ludzi natchnionych i proroków, to od nich zależy wypowiadanie tego, co powiedzieli i robienie tego, co zrobili, jakkolwiek wykonana została praca myślenia. Ale również nie twierdzimy, że to, co powiedzieli i to, co zrobili, było rezultatem ich pragnienia. W konsekwencji nie zależą od nas pewne myśli i reakcje afektywne, ani też czyny, które [powstały] w wyniku takiego myślenia i rozumowania. Pewne racje - jak mówił Filolaos - są mocniejsze od nas" (1225a28-33). Por. też EN III 7, 1115b7-10.

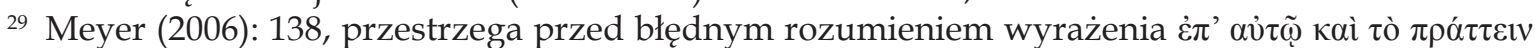

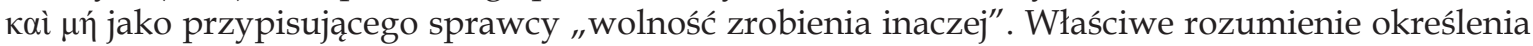
zakłada, że nasze działania są warunkowe, przy czym ich warunkowość nie jest efektem tego, że w naszej mocy leży to, że możemy coś zrobić lub nie. Jest raczej odwrotnie - ich warunkowość sprawia, że możemy coś zrobić lub nie. Chodzi więc o to, że wydarzenia dopuszczają, że może być inaczej, natomiast dzięki nam może stać się tak, że od nas będzie zależało, czy coś zrobimy, czy nie. ${ }^{30}$ Przypomnę, że Arystoteles polemizuje z Platonem i krytykuje go za głoszoną przez niego asymetrię pomiędzy dobrym i złym działaniem. Platon zakłada, że dobre działanie jest dobrowolne, natomiast

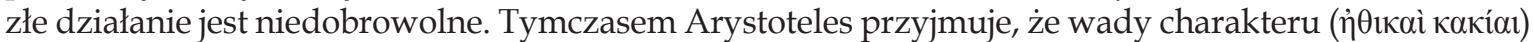
- jeden z elementów warunkujących zło-czynienie - zależą od nas (EN III 5,1113b6-13). Polemika z Platonem jest $w$ tej materii zrozumiała, ponieważ Arystoteles chce wykazać, że dobrowolne są nie tylko dobre działania, lecz również złe działania. Gdyby tylko pierwsze były dobrowolne, to podmiot działający nie ponosiłby odpowiedzialności za złe działania.
} 
co, w jaki sposób (1111a3-5). Jeżeli podmiot działający nie posiada wiedzy na temat jakiegoś z wymienionych czynników i brak tej wiedzy nie jest przez niego zawiniony, to jego działanie jest niedobrowolne, jeżeli natomiast jest zawiniony, to jego działanie jest dobrowolne. Zwraca na to uwagę Arystoteles, gdy podkreśla, że brak wiedzy daje podstawy do karania, jeżeli podmiot działający jest odpowiedzialny za swoją niewiedzę (III 5, 1113b30-31). Jeżeli więc uniknięcie niewiedzy było w mocy podmiotu działającego, to jego ignorancja jest dobrowolna i w konsekwencji, jego działanie również jest dobrowolne, pomimo nieznajomości wszystkich okoliczności, w których jest realizowane.

Biorąc pod uwage punkt A) należałoby przyjąć, że działanie jest dobrowolne, gdy zasada działania znajduje się w zmysłowo-orektyczej lub rozumnej „części" psuchē podmiotu działającego i od podmiotu zależy, czy działa, czy nie. W tym sensie, Arystoteles dokonuje reinterpretacji drugiej wspomnianej wyżej pary znaczeń, ponieważ może być tak, że podmiot działający przedsiębierze dane działanie pomimo tego, że nie czyni tego z ochotą ${ }^{31}$. Ale może też być tak, że auctor agendi działa pod wpływem reakcji afektywnej i robi to, czego by nie zrobil, gdyby nie był pod jej wpływem.

Gdy chodzi o punkt B) należałoby przyjąć, że działanie jest dobrowolne nie tylko wtedy, gdy podmiot działający wie, co jest właściwym celem ludzkiego życia i co jest potrzebne, aby osiągnąć go indywidualnie, a także dla wspólnoty politycznej, lecz również wtedy, gdy tego nie wie, ale źródłem braku tej wiedzy jest on sam. Dlatego karze się tych, którzy są ignorantami w kwestii praw, które znać trzeba i których poznanie nie jest trudne (1113b33-1114a1). Ale działanie jest dobrowolne również wtedy, gdy brak rozeznania co do określonych okoliczności realizowanego działania, jest zawiniony przez podmiot działający i w jego mocy było to wiedzieć. Dlatego ci, którzy działają wskutek upicia się lub wskutek bycia rozgniewanym, ponoszą odpowiedzialność za to, co robią, ponieważ wprawdzie nie wiedzą, co robią, ale ich czyny są bezwiedne nie wskutek niewiedzy ( $\delta \imath^{\prime}$ ă $\left.\gamma v o r \alpha v\right)$, lecz przez to, że się upili lub dali się rozgniewać (III 1, 1110b24-27). W konsekwencji, ich działania są dobrowolne.

\subsection{To, co dobrowolne i to, co niedobrowolne według EN V 8}

W EN III 1 Arystoteles odróżnia działanie dobrowolne od działania niedobrowolnego przy pomocy kryterium „pod przymusem” oraz kryterium „z niewiedzy”. Ale w ramach analizy pierwszego kryterium dochodzi do wniosku, że działanie jest dobrowolne pod warunkiem, że jest ono zależne od podmiotu działającego. Tymczasem w EN V 8 Arystoteles zdaje się sugerować, że to, co zachodzi „pod przymusem” oraz to, co „zależy od kogoś” występują jako osobne warunki ${ }^{32}$. Zauważa bowiem, że: „rzecz nieznana, albo rzecz znana, która jednak nie zależy od kogoś lub zachodzi pod przymusem, jest niedobrowolna" ${ }^{33}$.

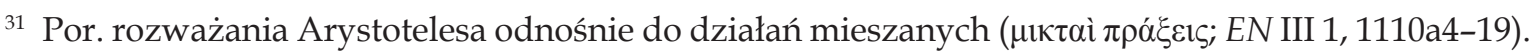
Na temat działań mieszanych zobacz np. Pakaluk (2011): 211-231.

${ }^{32}$ Zwraca na to uwagę np. Bostock (2000): 119.

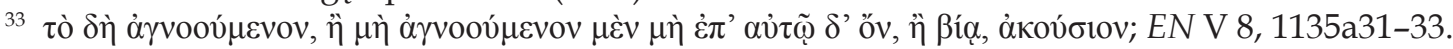


Ponieważ przyjmuje się, że księga O sprawiedliwości należy do wspólnych ksiąg ${ }^{34}$, więc nawiązanie do tego, co zostało wcześniej powiedziane (1135a23), może odnosić się nie tyle do EN III, ile do EE II. Takie przypuszczenie jest jednak niesatysfakcjonujące, ponieważ w EE II 8 Arystoteles rozważa to, co „zależy od kogoś” w połączeniu z tym, co nie zachodzi „pod przymusem”, a w II 9 dochodzi ostatecznie do konkluzji, że „o ile ktoś robi coś - nie w niewiedzy i sam z siebie - czego niezrobienie zależy od niego, to takie działanie jest z konieczności dobrowolne" (1225b8-9). Tak więc można wysunąć przypuszczenie, że w EE działanie jest dobrowolne pod warunkiem, że zależy od podmiotu działającego i nie jest realizowane w niewiedzy.

Ustęp EN V 8, 1135a31-33 można jednak rozumieć w ten sposób, że działanie, które jest niedobrowolne, jest dwojako określone. Można bowiem powiedzieć, że działanie jest niedobrowolne, gdy nie zależy od podmiotu działającego i to jest zasadnicza myśl. Ale można tę myśl wyrazić tak jak w III 1 i powiedzieć, że działanie jest niedobrowolne, gdy zachodzi pod przymusem i podmiot działający niczym się nie przyczynia do jego realizacji. Tak więc wyrażenie „lub zachodzi pod przymusem” może być po prostu skrótem myślowym. Chcąc je rozwinąć do pełnej postaci, należałoby powiedzieć „lub inaczej rzecz ujmując, zachodzi pod przymusem i podmiot działający niczym się nie przyczynia do jego realizacji". Fragment nie musi więc być odczytywany w taki sposób, który by sugerował, że „zależy od kogoś” i „,nie zachodzi pod przymusem” są osobnymi warunkami ${ }^{35}$.

Warto też zwrócić uwagę, że ustęp V 8, 1135a23-27, w którym Arystoteles wyjaśnia, jak rozumie to, co dobrowolne, daje się wyrazić tak, aby uniknąć mnożenia warunków dla działania dobrowolnego. Można go bowiem przełożyć w następujący sposób: „Przez dobrowolne - jak to też wcześniej zostało powiedziane - rozumiem to, co ktoś, z rzeczy zależnych od niego, robi świadomie, wiedząc kogo [działanie dotyczy], czym [je spełnia] i po co [je realizuje] (na przykład kogo uderza, czym i w jakim celu), czyli każda z tych rzeczy jednostkowych nie zachodzi ani przypadkowo, ani pod

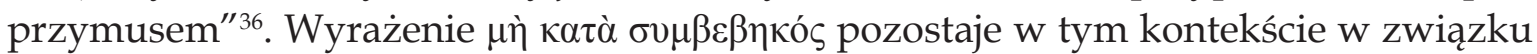
z niewiedzą partykularną ${ }^{37}$ i podkreśla, że brak wiedzy na temat czynników działania

${ }^{34} \mathrm{~W}$ EE i w EN występują trzy wspólne księgi: O sprawiedliwości $(E E \mathrm{IV}=E N \mathrm{~V}), \mathrm{O}$ cnotach intelektualnych $(E E \mathrm{~V}=E N \mathrm{VI})$ i O przyjemności $(E E \mathrm{VI}=E N \mathrm{~V})$. Kenny (1978) dowodzi, że wspólne księgi były pierwotnie częściami składowymi $E E$ i ten pogląd jest obecnie akceptowany. Kenny, [w:] Aristotle (2011) przygotował również nowe tłumaczenie $E E$ wraz z trzema wspólnymi księgami, które są numerowane według paginacji $E N$.

${ }^{35}$ Gauthier i Jolif, [w:] Aristote (1959): 398, powołując się na autorytet Michała z Efezu, sugerują, że można uniknąć w EN V 8 mnożenia warunków przy charakterystyce tego, co niedobrowolne, oddając drugą partykułę ì w EN V 8, 1135a32 eksplikatywnie, a nie dysjunktywnie. Tak zatem, działania, które byłyby niezależne od nas, byłyby po prostu działaniami dokonywanymi pod przymusem.

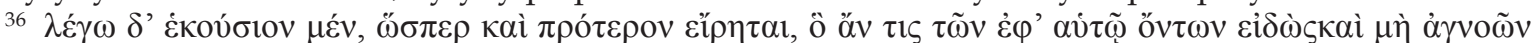

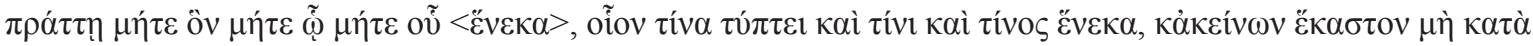

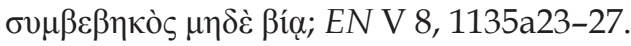

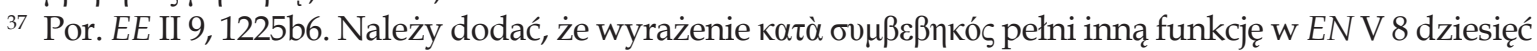
wierszy dalej, ponieważ odnosi się nie do niewiedzy partykularnej, lecz do realizowania danej rzeczy

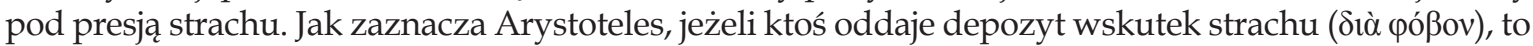
jego działanie nie jest sprawiedliwe, chyba że przypadkowo (1135b4-6). W istocie, Arystoteles stwierdza,

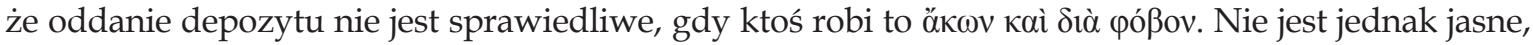

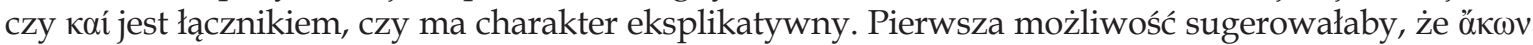
byłoby rozumiane zgodnie z użyciem tego terminu według drugiej pary znaczeń, druga możliwość wskazywałaby zaś na to, że działanie realizowane pod presją strachu jest dobrowolne. 
nie ma charakteru przypadkowego. To daje asumpt, aby uznać, że w grę wchodzi niewiedza, za którą odpowiada podmiot działający. Z kolei wyrażenie ßía podkreśla, że dane działanie nie jest dokonane pod przymusem i pozostaje $\mathrm{w}$ związku z warunkiem „zależy od kogoś"38.

Można więc zasugerować, że rezultaty badawcze, do jakich Arystoteles dochodzi w oparciu o przeprowadzone analizy w EN III 1 oraz V 8, nie odbiegają od siebie i wyjaśnienie, co jest dobrowolne, a co jest niedobrowolne, są w obu rozdziałach zbieżne.

\subsection{Typologia krzywd w EN V 8}

W EN V 8 Arystoteles zarysowuje również typologię krzywd. Z punktu widzenia rozważanej tu aporii, zagadnienie to jest o tyle ważne, że w ustępie V 9, 1136b13-25 Arystoteles zdaje się zakładać, iż nikt nie chce być traktowany niesprawiedliwie (1136b24). Z kolei w ustępie 1136a31-1136b1 zdaje się sugerować, że bycie niesprawiedliwym wobec samego siebie jest domeną akratyka. Arystoteles wyróżnia trzy typy krzywd - nieszczęśliwe wypadki, pobłądzenia oraz czyny niesprawiedliwe. Nie jest jednak do końca jasne, jak ów podział przebiega i jaki jest status wymienionych typów krzywd, biorąc pod uwagę kryterium "z niewiedzy” oraz rozróżnienie na działanie dobrowolne i niedobrowolne.

Po stwierdzeniu, że są trzy typy krzywd we wspólnotach, Arystoteles zauważa, że krzywdy, które powstają w połączeniu z niewiedzą, są pobłądzeniami (V 8, 1135b12). Ponieważ Arystoteles sugeruje, że w przypadku takich krzywd podmiot działający nie ma rozeznania co do czynników mających znaczenie z punktu widzenia realizowanego działania ${ }^{39}$, więc niewiedza, o którą chodzi w tym wypadku, jest niewiedzą partykularną. To z kolei może sugerować, że tak rozumiane wyrządzanie krzywdy jest działaniem niedobrowolnym. Arystoteles wprowadza jednak dalsze dookreślenie tego, czym jest pobłądzenie. Podkreśla bowiem, że do pobłądzenia dochodzi wtedy, gdy początek winy znajduje się w krzywdzącym (1135b18-19), a ponadto krzywda powstaje nie wbrew racjonalnemu przewidywaniu, choć nie z powodu wady charakteru krzywdzącego (1135b17-18). Z pobłądzeniem mamy do czynienia na przykład wtedy, gdy ktoś rzucił włócznią w niewolnika, aby go obudzić. Nie zwrócił jednak uwagi, że włócznia jest zakończona ostrym grotem. Zamiast wyrwać niewolnika z drzemki i pogonić go do pracy, uśmiercił go. Należałoby więc przyjąć, że niewiedza na temat czynników działania jest rezultatem zaniedbania czy też lekkomyślności podmiotu działającego i w związku z tym jest ona zawiniona przez niego. Wyrządzona krzywda jest więc działaniem dobrowolnym i podmiot działający ponosi odpowiedzialność za to, co się stało.

Drugi typ krzywd zostaje nazwany nieszczęśliwymi wypadkami (1135b17). Tutaj podmiot działający również nie ma rozeznania co do czynników działania, ale nie dlatego, że coś zaniedbał, lecz dlatego, że ich znajomość nie zależy od niego. Nieszczęśliwy wypadek ma bowiem miejsce wtedy, gdy początek winy leży poza podmiotem działa-

\footnotetext{
${ }^{38}$ Można też przyjąć, że warunek ",zależy od kogoś”, występujący w EN V 8, 1135a23-27, odnosi się do obu wyrażeń i podkreśla, że coś zależy od nas, gdy wykonujemy dane działanie nie pod przymusem i mając wiedzę na temat wszystkich okoliczności.

${ }^{39}$ Jak zauważa Arystoteles, czynniki działania w postaci "kogo", "czym" i „w jakim celu”, są inne, niż działający przypuszczał (EN V 8, 1135b13).
} 
jącym (1135b19) i krzywda powstaje wbrew racjonalnemu przewidywaniu (1135b16). Z nieszczęśliwym wypadkiem mamy do czynienia na przykład wtedy, gdy ktoś podał spragnionemu przyjacielowi szklankę wody nie wiedząc, że jest w niej trucizna. Zamiast ugasić pragnienie przyjaciela, doprowadził do jego śmierci. Należałoby więc przyjąć, że w tym wypadku niewiedza dotycząca czynników działania, jest niezawiniona przez podmiot działający. W konsekwencji, wyrządzona krzywda jest działaniem niedobrowolnym i podmiot działający nie ponosi odpowiedzialności za to, co się stało.

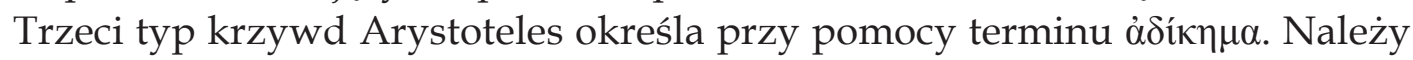

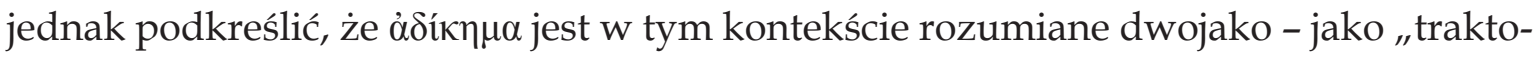
wanie niesprawiedliwie” oraz jako „akt niesprawiedliwości”. Rozróżnienie to wskazuje, że ten, kto traktuje niesprawiedliwie, nie jest jeszcze niesprawiedliwy, natomiast ten, kto dokonuje aktu niesprawiedliwości, jest już niesprawiedliwy ${ }^{40}$. Ponadto podkreśla się, że ten, kto traktuje niesprawiedliwie, lecz jeszcze nie jest niesprawiedliwy, po prostu błądzi (1135b22), natomiast ten, kto traktuje niesprawiedliwie i jest niesprawiedliwy, krzywdzi w sposób zamierzony (1135b25).

Dla aktu niesprawiedliwości charakterystyczne jest to, że podmiot działający

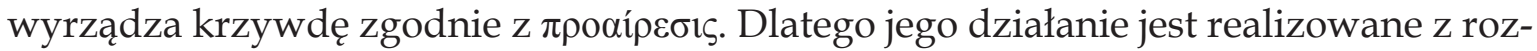
mysłem. Nie dziwi więc, że taki podmiot jest niesprawiedliwy i niegodziwy (1135b25). To zaś sugeruje, że brakuje mu wiedzy na temat tego, czym jest najwyższe dobro możliwe do osiągnięcia przez człowieka. Można więc przyjąć, że jego działania niesprawiedliwe zachodzą w połączeniu z niewiedzą, która jest niewiedzą ogólną. Skutkiem tego akty niesprawiedliwości są dobrowolne i ich auctor agendi ponosi za nie odpowiedzialność.

W przypadku traktowania niesprawiedliwie, podmiot działający wprawdzie jest świadomy, co robi, ale czyni to bez uprzedniego namysłu (1135b20). Można zatem przyjąć, że taki podmiot wyrządza krzywdę nie z rozmysłem i w konsekwencji nie w zgodzie z $\pi \rho \circ \alpha i ́ p \varepsilon \sigma ı$. Mimo to jego działanie jest dobrowolne, ponieważ zasada działania znajduje się w nim i od niego zależy, czy działa, czy nie. Tą zasadą są bowiem afekty zachodzące $\mathrm{w}$ jego psuchē $\mathrm{w}$ funkcji zmysłowo-orektycznej ${ }^{41}$. Zatem nawet jeśli ów podmiot nie wie do końca, co robi - wszak działanie powstaje w połączeniu z niewiedzą dotyczącą jego czynników - to niewiedza tego typu jest zawiniona przez sprawcę. W rezultacie podmiot wyrządzający krzywdę świadomie, ale bez premedytacji, ponosi odpowiedzialność za to, co robi.

Ponieważ ten, kto traktuje niesprawiedliwie, wyrządza krzywdę nie z $\pi \rho \alpha^{\prime} \rho \operatorname{coc} \varsigma$ i ponieważ źródłem krzywdzenia są reakcje afektywne lokujące się w jego psuchē, więc traktujący niesprawiedliwie robi to $\mathrm{w}$ wyniku utraty kontroli nad własnymi afektami.

${ }^{40}$ Należałoby dodać, że wprawdzie nie każde traktowanie niesprawiedliwie jest aktem niesprawiedliwości, ale każdy akt niesprawiedliwości jest zarazem traktowaniem niesprawiedliwie. Arystotelesowi zależy jednak na tym, aby pokazać, że można traktować niesprawiedliwie nie będąc jednocześnie niesprawiedliwym (por. np. EN V 6, 1134a16-17).

${ }^{41}$ Arystoteles podkreśla, że w tym wypadku wyrządzona krzywda powstaje wskutek gniewu lub innych afektów, które są naturalne dla ludzi lub przytrafiają się im automatycznie (EN V 8,

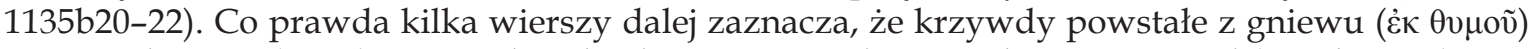
zapoczątkowuje (ö $\chi \chi \varepsilon 1)$ nie ten, kto działa w gniewie, lecz ten, kto rozgniewał (1135b26-27). Nie zmienia to jednak faktu, że wyrządzający krzywdę, w tym wypadku rozgniewany, nie panuje nad swoimi reakcjami afektywnymi. 
Można więc przyjąć, że traktujący niesprawiedliwie jest akratykiem. Przypuszczenie nie jest bezpodstawne, ponieważ charakterystyka podmiotu traktującego niesprawiedliwie, zarysowana w V 8, 1135b19-24, odpowiada charakterystyce akratyka, przedstawionej w księdze VII.

W V 8 Arystoteles, prócz już zaznaczonych rysów charakteryzujących wyrządzanie krzywdy w postaci traktowania niesprawiedliwego, wskazuje również na to, że podmiot traktujący niesprawiedliwie, nie jest niesprawiedliwy ani podły, ponieważ wyrządzona przez niego krzywda nie powstała wskutek niegodziwości (1135b24). Ale wszystkie wymienione rysy znajdują swój wyraz w księdze VII. Arystoteles podkreśla bowiem, że akratyk: a) nie jest niesprawiedliwy, ale traktuje niesprawiedliwie (np. 1151a10-11); b) w pewien sposób wie, co robi i w jakim celu (np. 1152a16); c) nie jest podły (np. 1152a17); d) nie potrafi przeprowadzić namysłu przed podjęciem działania (np. 1152a20) lub jeżeli udaje mu się taki namysł przeprowadzić, to wskutek afektów, nie potrafi trzymać się tego, co uprzednio obmyślił (np. 1151a1-3).

\section{Czy można być niesprawiedliwym wobec samego siebie?}

Zaznaczyłem we Wprowadzeniu, że rozwiązanie rozważanej aporii staje się oczywiste na bazie tego, co Arystoteles powiedział w EN V 9, w szczególności w ustępach bezpośrednio odnoszących się do aporii, czyli w 1136a31-1136b1 oraz 1136b13-25. Należy więc zbadać, do jakich ustaleń Arystoteles dochodzi w obu wymienionych ustępach.

\subsection{Ustęp 1136a31-1136b1}

W ustępie 1136a31-1136b1 Arystoteles stwierdza, co następuje:

Jeżeli zaś "traktowanie niesprawiedliwie" to po prostu krzywdzenie kogoś dobrowolnie - a "dobrowolnie" to wiedząc "kogo", ,czym” oraz ,jak" i akratyk krzywdzi samego siebie dobrowolnie - to akratyk byłby traktowany niesprawiedliwie dobrowolnie i byłoby możliwe traktowanie niesprawiedliwie samego siebie. Jest to także jeden z poruszanych problemów - czy można traktować niesprawiedliwie samego siebie ${ }^{42}$.

Mogłoby się wydawać, że pytanie „czy można traktować niesprawiedliwie samego siebie?”, jest bezprzedmiotowe. Niesprawiedliwość jest bowiem dyspozycją, której praktykowanie wymaga drugiego człowieka. W istocie niesprawiedliwość jest dyspozycją, która usposabia do przedsiębrania i urzeczywistniania aktów niesprawiedliwości, czyli rozmyślnego wyrządzania krzywd drugiemu człowiekowi. Z tego jednak, że ktoś traktuje kogoś niesprawiedliwie, nie wynika jeszcze, że cechuje go niesprawiedliwość w postaci ugruntowanej cechy charakteru.

W ustępie 1136a31-1136b1 Arystoteles bierze pod uwagę zachowanie akratyka. Tymczasem akratyk nie jest niesprawiedliwy nawet wtedy, gdy traktuje kogoś niespra-

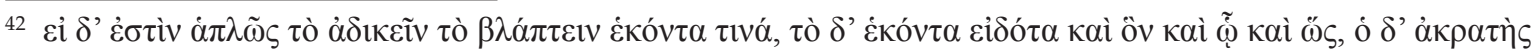

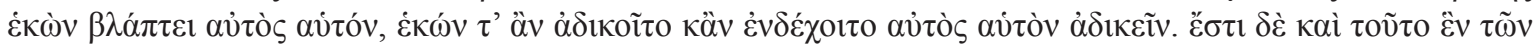

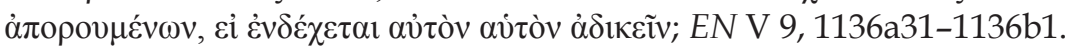


wiedliwie. Nie ma bowiem wykształconej cechy charakteru w postaci wady niesprawiedliwości. Ale czy to coś zmienia? Czy do traktowania niesprawiedliwie, podobnie jak do aktu niesprawiedliwości, nie dochodzi tylko w kontekście interpersonalnym? I czy w związku z tym, nie jest tak, że traktować niesprawiedliwie można tylko drugiego człowieka? Czy też przypadek akratyka dostarcza materiału, który skłania do wysunięcia przypuszczenia, że jednak można traktować niesprawiedliwie samego siebie?

Nie ulega wątpliwości, że Arystoteles rozważa taką ewentualność. Można się też domyślać, dlaczego to właśnie zachowanie akratyka jest przedmiotem jego zainteresowania. W przypadku akratyka jest możliwe bycie krzywdzonym dobrowolnie. Na przykład w EE VII, w ramach badania dotyczącego typologii przyjaźni, Arystoteles zauważa, że "krzywdzeni znoszą się wzajemnie dla przyjemności, tak długo jak długo są akratykami" (1236b16-17) ${ }^{43}$. Jeżeli „traktować niesprawiedliwie” oznacza „krzywdzić”, to traktowanie niesprawiedliwie samego siebie nie jest pozbawione sensu. Jeżeli więc traktowanie niesprawiedliwie samego siebie jest w ogóle możliwe, to należałoby doszukiwać się realizacji tej możliwości przede wszystkim w zachowaniu akratyka.

\subsubsection{Fenomen akrazji}

W EN VII Arystoteles bada stan charakteru zwany akrazją i czyni to w głównej mierze na tle stanu charakteru zwanego enkrazją. Ogólnie rzecz ujmując, wyrazem akrazji jest brak samokontroli, natomiast enkrazji - samokontrola. Oba stany charakteru wyrażają konflikt zachodzący w podmiocie działającym między pragnieniami alogicznymi, których źródłem jest psuchē w funkcji zmysłowo-orektycznej i pragnieniami logicznymi, których źródłem jest psuchē w funkcji rozumnej. Enkratykowi udaje się jednak wyprzeć lub pokonać reakcje afektywne oraz siły orektyczne, składające się na alogiczne pobudki do działania. Dzięki temu podporządkowuje się władzy rozumu i robi to, co ów rozum zaleca. Akratyk zaś „rozwiązuje” wewnętrzny konflikt w sposób przeciwny. Na skutek braku samokontroli podporządkowuje się alogicznym pragnieniom i robi to, na co rozum by nie zezwolił, gdyby działał efektywnie. O ile więc enkratyk robi to, co jest zgodne $\mathrm{z}$ zaleceniami rozumu, o tyle akratyk robi to, co takie nie jest.

Arystoteles zakłada jednak, że człowiek, jako całość złożona z różnych elementów, jest przede wszystkim tym, co jest w nim najbardziej autorytatywnym elementem (EN IX 8, 1168b31-33). Tym elementem zaś jest rozum. Zachowanie enkratyka jest więc nieprzydatne $w$ analizie rozważanej aporii, ponieważ pomimo wewnętrznego konfliktu pomiędzy psuchē w funkcji zmysłowo-orektycznej i psuchē w funkcji rozumnej, enkratyk idzie ostatecznie za głosem rozumu i zachowuje się jak przystało istocie racjonalnej. Ale zachowanie akratyka rodzi problem, ponieważ dowodzi, że są możliwe działania realizowane podług alogicznych poruszeń $p s u c h \bar{e}, \mathrm{z}$ równoczesnym zawieszeniem aktywności rozumu. Tak więc akratyk podąża nie za rozumem lub inaczej rzecz ujmując, nie za sobą jako istotą racjonalną, lecz za innym aspektem siebie, który jednak nie spełnia funkcji autorytatywnego elementu w strukturze bytu ludzkiego. Zachowanie akratyka jest więc nie bez znaczenia z punktu widzenia naszej aporii.

${ }^{43}$ Por. też EN V 9, 1136b1-2. 
W czym więc mogłoby się wyrażać „traktowanie niesprawiedliwie samego siebie" w przypadku akratyka? Aby zarysować odpowiedź na to pytanie, zwrócę uwagę na dwa miejsca w EN, czyli na ustępy IX 4, 1166a13-27 oraz IX 8, 1168b28-1169a19, które pozostają w związku z dyskusją na temat przyjaźni intrapersonalnej ${ }^{44}$. Ustępy są o tyle znaczące, że na ich podstawie można ujawnić paradygmatyczną formę zadowalania siebie, w której akratyk, z racji sposobu rozwiązywania wewnętrznego konfliktu, nie partycypuje.

\subsubsection{Paradygmatyczna forma zadowalania siebie, a zadowalanie siebie u akratyka}

W EN IX 4 Arystoteles wykazuje, że wzorcowy sposób okazywania oznak przyjaźni ( $\tau \grave{\alpha} \varphi \imath \lambda ı \kappa \alpha ́)$ znajduje swoje ucieleśnienie w sposobie odnoszenia się człowieka najwyższej próby ( $\sigma \pi \circ 0 \delta \alpha$ ĩo $)$ do samego siebie. Na bazie tego wzorca Arystoteles wyjaśnia, nie tylko czym jest doskonała forma przyjaźni interpersonalnej, lecz również czym jest prawdziwe miłowanie siebie. W 1166a13-27 Arystoteles zauważa, że człowiek najwyższej próby nie tylko chce dobrych rzeczy dla samego siebie, lecz również czyni je ze względu na samego siebie, a więc przez wzgląd na „część” uzdalniającą do myślenia (1166a14-17). Dalej dodaje, że „część" uzdalniająca do myślenia, czyli rozum, jest dzięki temu dobrze zaopatrzona w obiekty do kontemplowania (1166a26-27). Ponieważ cechą charakterystyczną człowieka najwyższej próby jest to, że troszczy się o rzeczywiste dobro (1166a15-16) i ponieważ w jego przypadku wspomnienia dokonanych uczynków są miłe (1166a24-25), więc można założyć, że owymi obiektami do kontemplowania są jego dobre uczynki.

W EN IX 8 Arystoteles przedstawia dwa typy samoluba - negatywnego i pozytywnego. Podział na samoluba negatywnego i samoluba pozytywnego pozostaje

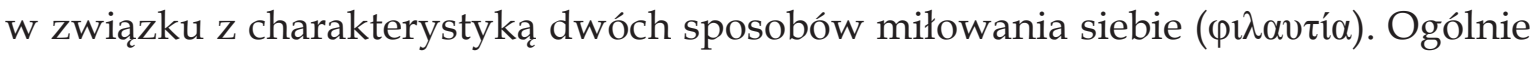
rzecz ujmując, samolub negatywny przekracza miarę w miłowaniu siebie, natomiast samolub pozytywny miłuje siebie, tak jak trzeba miłować siebie. O ile w przypadku samoluba negatywnego $\varphi \imath \lambda \alpha v \tau i ́ \alpha$ ogranicza się tylko do afektu, o tyle $\varphi \imath \lambda \alpha v \tau i ́ \alpha$ samoluba pozytywnego jest uczuciem, które zyskuje imprimatur rozumu. W 1168b28-1169a19 Arystoteles zaznacza, że człowiek najwyższej próby przydziela sobie największe dobra i zaspokaja najbardziej autorytatywny element samego siebie, a więc rozum (1168b29-31). Podkreśla jednak, że ten rodzaj zaspokajania dokonuje się dzięki temu, że człowiek najwyższej próby robi wiele rzeczy ze względu na przyjaciół i ze względu na ojczyznę (1169a18-19). Chodzi więc o realizację takich czynów, które przysparzają dobra innym i wspólnocie. Nie zmienia to jednak faktu, że dzięki takim działaniom człowiek najwyższej próby pozyskuje to, co piękne tylko dla siebie. Nie sposób bowiem dostarczyć drugiemu człowiekowi nośnika piękna, czyli dobro-czynienia. To, co faktycznie można dostarczyć drugiemu człowiekowi, to efekt dobro-czynienia, czyli dobrodziejstwo ${ }^{45}$. Tak więc piękno przypada w udziale nie temu, kto jest bierny, lecz temu, kto jest aktywny ${ }^{46}$.

Uwzględniwszy oba ustępy, można wysunąć przypuszczenie, że człowiek najwyższej próby zadowala siebie jako istotę racjonalną. Ponieważ rozum w ujęciu Arysto-

\footnotetext{
${ }^{44}$ Na temat przyjaźni intrapersonalnej zobacz: Smolak (2013): 307-325.

${ }^{45}$ EN IX 7, 1168a9-12.

${ }^{46}$ Por. np. Politis (1993): 166.
} 


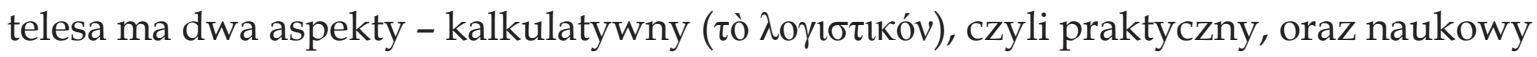

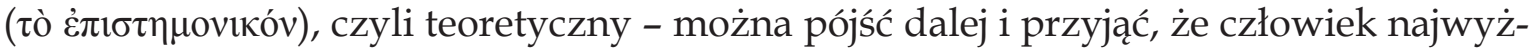
szej próby, niejako symultanicznie, zadowala oba aspekty najbardziej autorytatywnego elementu samego siebie. Pierwszy zaspokaja w tym sensie, że przedsiębierze to, co rozum w funkcji praktycznej zaleca do przedsiębrania. Drugi zaspokaja w tym sensie, że dostarcza obiektów noetycznych, dzięki którym rozum w funkcji teoretycznej może przejść w doraźny stan najbardziej eudaimonicznej aktywności, czyli kontemplowania $(\theta \varepsilon \omega \rho i ́ \alpha)$. Jak zauważa Arystoteles, piękno jest jednym z obiektów godnych wyboru do kontemplowania ${ }^{47}$.

Kim jednak jest człowiek najwyższej próby? Zdaniem Arystotelesa jest on miarą tego, co dobre dla człowieka (EN IX 4, 1166a12-13). Cechuje go bowiem umiejętność dostrzegania prawdy w przypadku każdego obiektu chcenia i formułowania trafnej oceny na jego temat ${ }^{48}$. W gruncie rzeczy człowiek najwyższej próby nie tylko wie, jakie życie jest najbardziej udane, lecz również urzeczywistnia je w praktyce. Jeżeli więc człowiek najwyższej próby - miara tego, co dobre dla człowieka - zadowala siebie jako istotę racjonalną, to można przyjąć, że zadowalanie siebie jako istoty racjonalnej, jest czymś dobrym dla człowieka.

A jak jest w przy padku akratyka? Otóż akratyk, jeżeli w ogóle zadowala siebie, to nie jako istotę racjonalną, lecz jako istotę zmysłowo-orektyczną, ponieważ dostarcza sobie mniej, niż się należy jako istocie racjonalnej i równocześnie więcej, niż się należy jako istocie zmysłowo-orektycznej. Można to też wyrazić w ten sposób, że akratyk zadowala siebie jako istotę zmysłowo-orektyczną kosztem siebie jako istoty racjonalnej. Jeżeli tak jest ${ }^{49}$, to akratyk mógłby, jako istota zmysłowo-orektyczna, traktować niesprawiedliwie samego siebie i mógłby też, jako istota racjonalna, być traktowany niesprawiedliwie przez samego siebie. W gruncie rzeczy, obiekty, które akratyk dostarcza sobie do oglądania, sprawiają mu przykrość, ponieważ wspomnienia dokonanych uczynków nie są dla niego miłe. Wszak akratyk jest skłonny do odczuwania żalu i zawsze go odczuwa po czynie dokonanym w trybie akrazji (EN VII 8, 1150b30-31). Zdaje sobie bowiem sprawę, że to, co zrobil, nie harmonizuje z jego przekonaniami i nie zgadza się z tym, czego domagał się jego rozum. Dlatego obiekty, które dostarcza sobie do oglądania, nie mogą go zadowalać.

Ale czy w takim razie przypuszczenie, że akratyk traktuje niesprawiedliwie samego siebie, nie staje się wiarygodne? Czy nie staje się ostatecznie jasne, że jednak można traktować niesprawiedliwie samego siebie? Problem w tym, że ustęp 1136a31-1136b1 nie przynosi jednoznacznego rozstrzygnięcia, o czym świadczy jego podsumowanie: "Jest to także jeden z poruszanych problemów - czy można traktować niesprawiedliwie samego siebie".

\footnotetext{
47 Por. Metafizyka XII 7, 1072a34-35.

${ }^{48}$ Por. EN III 6, 1113a29-30.

${ }^{49}$ Por. EN IX 8, 1168b15-21.
} 


\subsection{Ustęp 1136b14-25}

W ustępie 1136b14-25 Arystoteles stwierdza, co następuje:

Są jeszcze dwie rzeczy, o których zamierzyliśmy powiedzieć. Czy traktuje niesprawiedliwie ten, kto udzielił więcej ponad zasługę, czy ten, kto ma [więcej ponad zasługę, i czy jest możliwe traktowanie niesprawiedliwie samego siebie. Jeżeli bowiem jest możliwa pierwsza ze wspomnianych rzeczy i traktuje niesprawiedliwie ten, kto przydziela więcej, a nie ten, kto ma więcej, to jeżeli ktoś świadomie i chętnie udziela więcej komuś innemu, niż sobie, to traktuje niesprawiedliwie samego siebie. To właśnie zdają się robić ludzie umiarkowani, ponieważ człowiek przyzwoity jest skłonny do ustępstw. Czy i to nie jest [takie] proste? Wszedł bowiem w posiadanie większej ilości innego dobra, jeżeli się udało - na przykład czci lub po prostu czegoś pięknego.

Ponadto [aporię] rozwiązuje się podług określenia „traktować niesprawiedliwie". [Nikt] bowiem nie zaznaje od siebie niczego wbrew życzeniu. W konsekwencji, [nikt] nie jest traktowany niesprawiedliwie [przez samego siebie] - w każdym razie $\mathrm{z}$ tego powodu - lecz jeżeli w ogóle, to jest jedynie krzywdzony ${ }^{50}$.

W przytoczonym ustępie Arystoteles przedstawia dwa argumenty na rzecz niemożliwości traktowania niesprawiedliwie samego siebie. Pierwszy nazywam argumentem „z pozornej straty”, drugi określam argumentem „z życzenia”.

\subsubsection{Argument "z pozornej straty"}

Argument „z pozornej straty” bada aporię w kontekście interpersonalnym i w oparciu o hipotetycznie przyjęte rozwiązanie innej trudności. Nie jest bowiem jasne, czy traktuje niesprawiedliwie ten, kto przydzielił komuś więcej ponad jego zasługę, czy ten, kto przyjął więcej ponad to, co mu się należało. Arystoteles zakłada, że traktuje niesprawiedliwie ten, kto przydzielił komuś więcej, niż mu się należało, a nie ten, kto to przyjął. Jeżeli więc ktoś świadomie i chętnie przydziela więcej komuś innemu, niż sobie, to wydaje się, że faktycznie ów ktoś traktuje niesprawiedliwie samego siebie. Robi to wszak dobrowolnie. To by zaś oznaczało, że traktowanie niesprawiedliwie samego siebie jest możliwe.

Arystoteles przestrzega jednak przed bezkrytycznym przyjęciem takiego rozwiązania. Ktoś, kto w ten sposób postępuje, robi to w pewnym celu. Chodzi mu bowiem o to, aby pozyskać dobro, które jest dla niego cenniejsze od tego, które traci. Wprawdzie może się mylić w swoich kalkulacjach i włożony wkład pozostanie nie zrekompensowaną stratą. Zwraca na to uwagę Arystoteles, gdy zaznacza „jeżeli się udało” (1136b21). Jednakowoż przydzielający więcej komuś innemu, niż sobie, zakłada, że to, co pozyska,

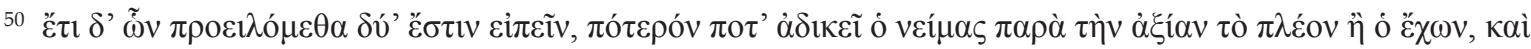

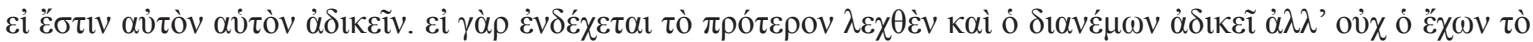

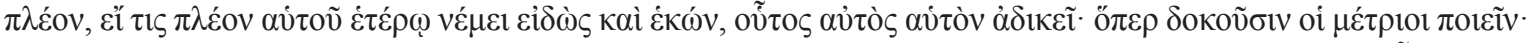

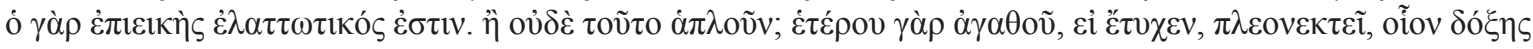

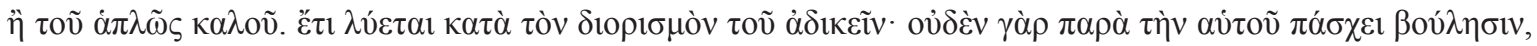

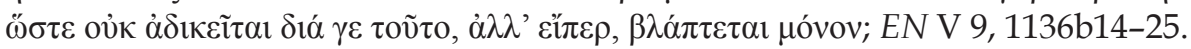


przewyższy wartością poniesione koszty. Wszak ma wejść w posiadanie większej ilości innego dobra - na przykład czci, o której Arystoteles mówi, że jest największym z dóbr zewnętrznych ${ }^{51}$. Zatem ktoś, kto świadomie i chętnie przydziela więcej komuś innemu, niż sobie, nie traktuje niesprawiedliwie samego siebie, ponieważ ostateczny rachunek strat i zysków jest dla niego korzystny.

Argument „z pozornej straty” daje się rozwinąć. Można bowiem założyć, że ten, kto przydziela więcej komuś innemu niż sobie, robi to po namyśle, skoro ma na celu pozyskanie dobra, które zrekompensuje poniesioną stratę. To by zaś oznaczało, że

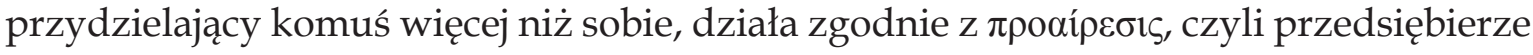
to, co obmyślił i postanowił zrealizować. Tymczasem „nikt - jak podkreśla Arystoteles - nie postanawia krzywdzić samego siebie i dlatego nie ma niesprawiedliwości wobec samego siebie" (EN V 6, 1134b12-13).

Czego jednak dowodzi argument „z pozornej straty”? Dowodzi, że nie można

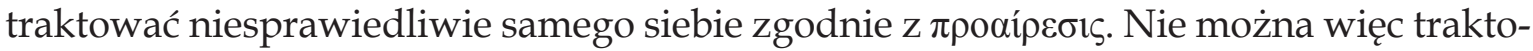
wać niesprawiedliwie samego siebie z rozmysłem, czyli dokonywać aktu niesprawiedliwości wobec samego siebie. Z tego jednak nie wynika, że w ogóle nie można traktować niesprawiedliwie samego siebie. W punkcie 1.3 niniejszego artykułu zostało pokazane, że "traktowanie niesprawiedliwie” jest pojęciem szerszym od „aktu niesprawiedliwości”. Każdy bowiem akt niesprawiedliwości jest traktowaniem niesprawiedliwie, ale nie każde traktowanie niesprawiedliwie jest aktem niesprawiedliwości. Aporia pozostaje więc dalej nierozwiązana, ponieważ nie zostało wykluczone, że akratyk nie może traktować niesprawiedliwie samego siebie. Można nawet zasugerować, że w sytuacji, gdy się właśnie „nie

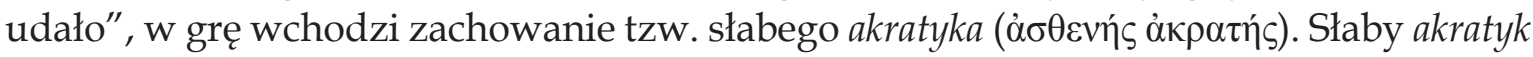
charakteryzuje się tym, że jest zdolny do przeprowadzenia namysłu przed podjęciem

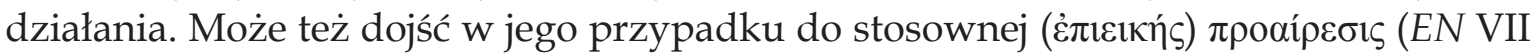
10, 1152a17). Mimo to, na skutek afektów, nie potrafi wytrwać przy tym, co obmyślił i co przedsięwziął. Można zatem przyjąć, że strata słabego akratyka nie jest pozorna, lecz rzeczywista, choć niezamierzona. I w tym sensie w przypadku słabego akratyka mogłoby dojść do traktowania niesprawiedliwie samego siebie.

\subsubsection{Argument "z życzenia"}

Argument „z życzenia” rozpatruje aporię w oparciu o wcześniej wyeksplikowane określenie wyrażenia "traktować niesprawiedliwie”. W grę wchodzą przede wszystkim dwa wyjaśnienia. Pierwsze pojawia w EN V 8, w ramach badania dotyczącego typologii krzywd. Zgodnie z nim, "traktować niesprawiedliwie” to tyle, co wyrządzać krzywdę świadomie, lecz bez uprzedniego obmyślenia oraz wskutek afektu naturalnego dla człowieka. Tak rozumiane traktowanie niesprawiedliwie, jest wyrządzaniem krzywd charakterystycznym dla akratyk $a^{52}$. Drugie wyjaśnienie pojawia się w V 9, bezpośrednio po ustępie 1136a31-1136b1. Arystoteles dochodzi do niego stopniowo. W punkcie wyjścia stwierdza, że „ktoś może być dobrowolnie krzywdzony przez kogoś innego wskutek

\footnotetext{
${ }^{51}$ Por. EN IV 3, 1123b17-21.

${ }^{52}$ Por. punkt 1.3. niniejszego artykułu.
} 
akrazji" (1136b1-2). Takie postawienie sprawy sugeruje, że ktoś, kto jest akratykiem, może aprobować wyrządzaną mu krzywdę. Stąd też konkluzja: „można być dobrowolnie traktowanym niesprawiedliwie" (1136b2-3). Uzyskany wynik jest jednak niesatysfakcjonujący. W istocie, akratyk nie może być dobrowolnie traktowany niesprawiedliwie, ponieważ - jak dodaje Arystoteles - nikt tego nie chce, nawet akratyk (1136b6). Stąd modyfikacja konkluzji: „,do ,krzywdzić wiedząc kogo, czym i jak' trzeba dodać ,wbrew życzeniu krzywdzonego'" ${ }^{\prime \prime}$.

Jaki jest zatem rezultat? Jest oczywiste, że traktowanie niesprawiedliwie wymaga podmiotu działającego i podmiotu doznającego, „nie jest bowiem możliwe bycie traktowanym niesprawiedliwie bez tego, kto traktuje niesprawiedliwie" (1136a29-30). Ale w myśl argumentu „z życzenia”, o ile „traktować niesprawiedliwie” można tylko dobrowolnie, o tyle „być traktowanym niesprawiedliwie” można tylko wbrew własnemu życzeniu. Gdyby więc podmiot działający był tym samym podmiotem, który doznaje, to musiałby traktować niesprawiedliwie samego siebie dobrowolnie i równocześnie nie chcieć być traktowanym niesprawiedliwie. Nikt zaś nie chce tego, co jest przeciwne jego życzeniu. I to właśnie podkreśla argument „z życzenia”: ,[nikt] bowiem nie zaznaje od siebie niczego wbrew życzeniu" (1136b23-24). W rezultacie "[nikt] nie jest traktowany niesprawiedliwie [przez samego siebie]" (1136b24). A zatem traktowanie niesprawiedliwie samego siebie jest po prostu niemożliwe. Nie można bowiem chcieć czegoś i równocześnie nie chcieć tego czegoś ${ }^{54}$.

Można mieć jednak wątpliwości, czy argument „z życzenia” dostarcza jednoznacznego rozwiązania aporii ${ }^{55}$. I Arystoteles ma tego świadomość, o czym może świadczyć dodane zastrzeżenie do konkluzji argumentu: „w każdym razie z tego powodu” (1136b24). Zastrzeżenie podkreśla, że nie można chcieć być traktowanym niesprawie-

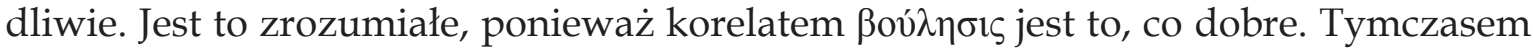
bycie traktowanym niesprawiedliwie jest czymś złym. Dodane zastrzeżenie nie wyklucza jednak, że ktoś może pragnąć być traktowanym niesprawiedliwie innym typem pra-

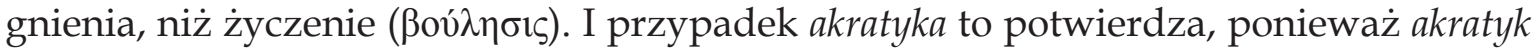

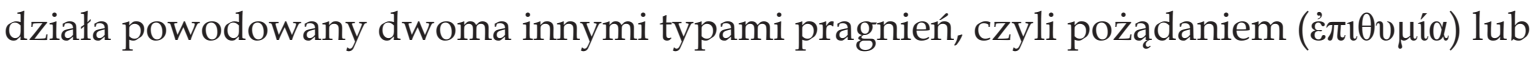
zapalczywością ( $\theta u$ rós). Tak więc akratyk może działać wbrew własnemu życzeniu. Może więc być traktowany niesprawiedliwie dobrowolnie, wprawdzie nie dlatego, że tego chce, lecz z powodu własnego pożądania lub zapalczywości. Wszak akratyk nie robi tego, o czym sądzi, że trzeba to robić (1136b8). Robi natomiast to, o czym sądzi, że nie należy tego robić. Pragnie bowiem przyjemności, która jawi mu się jako coś dobrego, mimo że nie uważa jej za coś dobrego ${ }^{56}$. Zatem argument „z życzenia” nie wyklucza możliwości dobrowolnego bycia traktowanym niesprawiedliwie przez samego siebie. W konsekwencji, nie dowodzi, że jest niemożliwe traktowanie niesprawiedliwie samego siebie.

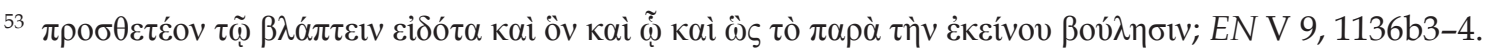

54 Por. np. Curzer (1998): 223.

55 Por. np. Broadie, [w:] Aristotle (2002): 353.

56 Por. EE VII 2, 1235b26-28.
} 


\section{Zakończenie}

To, co jest powiedziane w ustępach 1136a31-1136b1 oraz 1136b14-25, nie dowodzi, że Arystoteles dostarcza jednoznacznego rozwiązania analizowanej aporii. W ustępie 1136a31-1136b1 Stagiryta tylko problematyzuje zagadnienie, wysuwając hipotezę, że przypadek akratyka może potwierdzać możliwość traktowania niesprawiedliwie samego siebie. Z kolei w ustępie 1136b14-25 Arystoteles formułuje dwa argumenty - argument „Z pozornej straty” oraz argument „z życzenia" - których celem jest udowodnienie, że nie jest możliwe traktowanie niesprawiedliwie samego siebie. Argumenty te nie unieważniają hipotezy postawionej w pierwszym ustępie i nie wykluczają możliwości traktowania niesprawiedliwie samego siebie przez akratyka. Czy zatem stwierdzenie, że „jest jasne, na podstawie tego, co zostało powiedziane, czy można traktować niesprawiedliwie samego siebie, czy nie" (EN V 11, 1138a4-5), jest zasadne?

W pewnym sensie tak, ponieważ jest jasne, że ten, kto jest niesprawiedliwy, nie może traktować niesprawiedliwie samego siebie. Jest zatem oczywiste, że nie można być niesprawiedliwym wobec samego siebie z rozmysłem, tzn. nie jest możliwe urzeczywistnianie aktu niesprawiedliwości wobec samego siebie. Tylko że taka konstatacja staje się trywialna, skoro niesprawiedliwość, czyli dyspozycja usposabiająca do przedsiębrania aktów niesprawiedliwości, wymaga do jej praktykowania obecności drugiego człowieka.

Na koniec można dodać, że przypadek akratyka stawia pod znakiem zapytania możliwość asymetrycznego rozwiązania aporii „czy można być niesprawiedliwym wobec samego siebie?”. Jego bowiem postępowanie wobec samego siebie jest wyrazem dobrowolnego krzywdzenia samego siebie. Jest ono dobrowolne, ponieważ jest powodowane przez jego reakcje afektywne i siły orektyczne, składające się na alogiczne pobudki do działania. Jest ono krzywdzeniem samego siebie, ponieważ jest odbieraniem sobie szansy prowadzenia eudaimonicznego życia.

\section{Bibliografia}

Ajschylos (1959), Prometeusz w okowach, [w:] Ajschylos, Tragedie, tłum. S. Srebrny, PWN, Warszawa: 166-216.

Aristote (1959), L'Éthique à Nicomaque, t. II : Commentaire, cz. 1 i 2, R.A. Gauthier, J.Y. Jolif (red., tłum.), Publications Universitaires, Louvain.

Aristoteles (1960), Aristotelis Opera, A.I. Bekker, Ch.A. Brandis, O. Gigon (red., tłum.), Deutsche Akademie Wissenschaften, Berlin.

Aristotle (1931), The Nicomachean Ethics, tłum. W.D. Ross, Oxford University Press, Humphrey Mildfold, London.

Aristotle (1998), Nicomachean Ethics. Books VIII and IX, tłum. M. Pakaluk, Clarendon Press, Oxford.

Aristotle (2002), Nicomachean Ethics, tłum. Ch. Rowe, Oxford University Press, New York. Aristotle (2004), Nicomachean Ethics, tłum. R. Crisp, Cambridge University Press, Cambridge. Aristotle (2011), The Eudemian Ethics, tłum. A. Kenny, Oxford University Press, Oxford.

Arnold D.G. (2011), Coercion and Moral Responsibility, "American Philosophical Quarterly" 38 (1): 53-67.

Arystoteles (1956), Etyka nikomachejska, tłum. D. Gromska, PWN, Warszawa. 
Bondeson W. (1974), Aristotle on Responsibility for One's Character and the Possibility of Character Change, „Phronesis” 19 (1): 59-65.

Bostock D. (1988), Pleasure and Activity in Aristotle's Ethics, „Phronesis” 33 (3): 251-272.

Bostock D. (2000), Aristotle's Ethics, Oxford University Press, Oxford.

Charles D. (2011), Akrasia: The Rest of the Story?, [w:] Moral Psychology and Human Action in Aristotle, M. Pakaluk, G. Pearson (red.), Oxford University Press, Oxford: 187-209.

Dow J. (2011), Aristotle's Theory of the Emotions: Emotions as Pleasures and Pain, [w:] Moral Psychology and Human Action in Aristotle, M. Pakaluk, G. Pearson (red.), Oxford University Press, Oxford: 47-74.

Festugière A.J. (1946), Aristote. Le plaisir. Introduction, traduction et notes, Vrin, Paris.

Frede D. (2006), Pleasure and Pain in Aristotle's Ethics, [w:] The Blackwell Guide to Aristotle's Nicomachean Ethics, R. Kraut (red.), Blackwell Publishing Ltd., Malden, Oxford, Carlton, Victoria: 255-275.

Galewicz W. (2003), Z Arystotelesem przez greckie tragedie, cz. 2: O błądzeniu, przymusie i dobrowolności, Wydawnictwo Literackie, Kraków.

Galewicz W. (2019), Odpowiedzialność i sprawiedliwość w etyce Arystotelesa, Wydawnictwo Marek Derewiecki, Kęty.

Hardie W.F.R. (1968), Aristotle's Ethical Theory, Clarendon Press, Oxford.

Heinaman R. (2011), Pleasure as an Activity in the Nicomachean Ethics, [w:] Moral Psychology and Human Action in Aristotle, M. Pakaluk, G. Pearson (red.), Oxford University Press, Oxford: 1-46.

Hursthouse R. (1984), Acting and Feeling in Character: Nicomachean Ethics 3.i., "Phronesis” 29 (3): 252-266.

Irwin T.H. (1980), Reason and Responsibility in Aristotle, [w:] Essays on Aristotle's Ethics, A.O. Rorty (red.), University of California Press, Berkeley, Los Angeles: 117-155.

Kenny A. (1978), The Aristotelian Ethics, Clarendon Press, Oxford.

Moline J.N. (1989), Aristotle on Praise and Blame, "Archiv für Geschichte der Philosophie" 71 (3): 283-302.

Meyer S.S. (2006), Aristotle on the Voluntary, [w:] The Blackwell Guide to Aristotle's Nicomachean Ethics, R. Kraut (red.), Blackwell Publishing Ltd., Malden, Oxford, Carlton, Victoria: 137-157.

Natali C. (2009), Nicomachean Ethics, Book VII. Symposium Aristotelicum, C. Natali (red.), Oxford University Press, Oxford.

Ortiz de Landázuri M.C. (2012), Aristotle on Self-Perception and Pleasure, "Journal of Ancient Philosophy" 6 (2): 1-17.

Owen G.E.L. (1971/2), Aristotelian Pleasures, „Proceedings of the Aristotelian Society”, 72: 132-152.

Pakaluk M. (2005), Aristotle's Nicomachean Ethics, Cambridge University Press, Cambridge.

Pakaluk M. (2011), Mixed Actions and Double Effect, [w:] Moral Psychology and Human Action in Aristotle, M. Pakaluk, G. Pearson (red.), Oxford University Press, Oxford: 211-231.

Pangle L.S. (2004), Aristotle and the Philosophy of Friendship, Cambridge University Press, Cambridge.

Platon (2017), Prawa, tłum. D. Zygmuntowicz, Wydawnictwo Marek Derewiecki, Kęty.

Politis V. (1993), The Primacy of Self-Love in the Nicomachean Ethics, "Oxford Studies in Ancient Philosophy" 11: 153-174.

Price A.W. (1989), Love and Friendship in Plato and Aristotle, Oxford University Press, Oxford. Price A.W. (2011), Virtue and Reason in Plato and Aristotle, Oxford Clarendon Press, Oxford. 
Smolak M. (2013), Przyjaźń w świetle etyki Arystotelesa, Wydawnictwo Uniwersytetu Jagiellońskiego, Kraków.

Skowroński L. (2014), Arystoteles o celu życia. Ku nowej interpretacji Etyki nikomachejskiej, Wydawnictwo Rolewski, Nowa Wieś.

Sofokles (2009), Edyp w Kolonos, [w:] Sofokles, Tragedie, t. I, tłum. R.R. Chodkowski, Towarzystwo Naukowe Katolickiego Uniwersytetu Lubelskiego Jana Pawła II, Lublin: 411-507.

Sowa J. (2009), Miedzy Erosem i Aretē. Przyjaźn w etyce Platona i Arystotelesa, Wydawnictwo Uniwersytetu Łódzkiego, Łódź.

Stern-Gillet S. (1995), Aristotle's Philosophy of Friendship, State University of New York Press, Albany.

Wesoły M. (2012), Dusza żywienna (wegetatywna) zwierząt w koncepcji Arystotelesa, [w:] Człowiek w świecie zwierząt - zwierzęta w świecie człowieka, K. Ilski (red.), Wydawnictwo Naukowe UAM, Poznań: 87-106. 